\title{
Cultural Diversity and Universal Ethics in a Global World
}

\author{
Domènec Melé $\cdot$ Carlos Sánchez-Runde
}

Received: 3 March 2013/Accepted: 1 July 2013/Published online: 7 August 2013

(C) Springer Science+Business Media Dordrecht 2013

\begin{abstract}
Cultural diversity and globalization bring about a tension between universal ethics and local values and norms. Simultaneously, the current globalization and the existence of an increasingly interconnected world seem to require a common ground to promote dialog, peace, and a more humane world. This article is the introduction to a special issue of the Journal of Business Ethics regarding these problems. We highlight five topics, which intertwine the eight papers of this issue. The first is whether moral diversity in different cultures is a plausible argument for moral relativism. The second focuses on the possibility of finding shared values and virtues worldwide. The third topic deals with convectional universalistic ethical theories in a global world and the problems they present. Fourth, we consider the traditional natural moral law approach in the context of a global world. The last topic is about human rights, as a practical proposal for introducing universal standards in business.
\end{abstract}

Keywords Cultural diversity - Universal ethics ·

Relativism · Globalization - Natural law ·

Human rights

\section{Introduction}

Differences in race, sex, language, ethnicity, values systems, religion, and local practices are important aspects of the business environment in both domestic and international business. Cultural diversity not only matters to business management, but also to policy makers and international organizations. It is, of course, relevant for

D. Melé $(\varangle)$ C C. Sánchez-Runde

IESE Business School, Barcelona, Spain

e-mail: mele@iese.edu business ethics, too. Organizing corporations so that people from different cultures live and work together peacefully is a challenge for management that we cannot ignore.

The last few decades have witnessed the development of cross-cultural management, which focuses on cultural differences and their effect on organizational and managerial decision-making. Cross-cultural management is not only a question of techniques. It involves human and ethical considerations, as does every other aspect of management (Melé 2012). Beyond cultural diversity, management is about people and so it entails ethical dimension.

Cultural diversity entails an ethical challenge, for different reasons. One is that there are differences on moral perceptions and moral judgments among cultures, and consequently a tension appears between moral universalism (universal ethical principles or standards) and moral cultural relativism (local or cultural ethical norms as the exclusive source for ethical standards) (Donaldson 1996; Jhingran 2001; Frederick 2002; Vendemiati 2008; among others). Some may defend that the old chestnut, "when in Rome do as Romans do," still has currency. This saying does not offer ethical difficulties if you apply it with regard to certain customs, but it is problematic if you apply it to ethical matters-then it leads to moral relativism. At the other extreme we find those who defend acting in accordance with one's home cultural values and norms, which often merits the accusation of "cultural imperialism." Others, to avoid both cultural relativism and imperialism, prefer to say "when in Rome do as the best Romans do." This improves the former by introducing a sense of discernment, but no-one can be sure that even the best Romans always acted in accordance with high standards of morality. We should remember, for instance, that for a long time slavery was acceptable even for the best Romans, and in certain countries or places corruption was so extensive 
that it would have been very difficult to find a virtuous person abstaining from corrupting practices. Apart from this, acritically accepting other people's behavior, or the values of the majority, as one's moral standard means ignoring personal conscience and thus the first personal moral obligation of sincerely seeking the virtuous and right thing to do in each situation.

In spite of these and other objections, some ethicists are in favor of moral relativism, while others insist on the shortcomings of this position and defend moral universalism (Krausz 1989). A third group holds a balanced position between universalism, expressed through a set of basic ethical values or principles, and particular cultural norms (Donaldson 1996; Gowans 2012) or are looking for empirical or philosophical bases to promote global ethics (e.g., Küng 1998 and ITC 2009, respectively).

The debate on ethical relativism and universal ethics, which is still open, has important consequences for both business ethics and cross-cultural management. Some opt for accepting ethical relativism, while others offer strong arguments against this. In addition, some events, such as corporate scandals and corruption, violation of certain basic human rights and environmental issues question ethical relativism at least in some matters.

Apart from this debate, there is a pragmatic reason to seek and promote universalism and common values: the current globalization and the existence of an increasingly interconnected world. According to Bok, "the need to pursue the inquiry about which basic values can be shared across cultural boundaries is urgent, if societies are to have some common ground for cross-cultural dialog and for debate about how best to cope with military, environmental, and other hazards that, themselves, do not stop at such boundaries." (2002, p. 13).

The Parliament of the World's Religions (1993), seeking consensus on common ethical values, stated that there will be no better global order without a global ethic, which cannot be created or enforced by laws, prescriptions, or conventions alone. On its part, the International Theological Commission (ITC) praised those who work in seeking common ethical values, assessing that "only the recognition and promotion of these ethical values can contribute to the construction of a more human world." But, at the same time, stresses the necessity of achieving a sound foundation by affirming: "these efforts cannot succeed unless good intentions rest on a solid foundational agreement regarding the goods and values that represent the most profound aspirations of man, both as an individual and as member of a community." (ITC 2009, n. 2).

These and other related topics were discussed in the 17th IESE International Symposium on "Ethics, Business and Society," in Barcelona, Spain, on May 14-15, 2012 under the theme "Universal Ethics, Cultural Diversity and
Globalization." This issue of the Journal of Business Ethics publishes a collection of papers presented at this Symposium. Our aim is to introduce the articles selected within a framework on cultural diversity and universal ethics intertwining the contributions included in this issue. We structure this presentation by focusing on five relevant aspects treated in the Symposium. Firstly, we ask whether or not moral diversity of different cultures is a good argument for moral relativism. Secondly, we consider the existence of shared values and virtues worldwide, and some managerial inferences. Thirdly, we wonder if universalistic ethical theories are appropriate in a global world facing development problems. Fourthly, we deal with the traditional proposal of natural moral law in the context of a global world. In the fifth part, we focus on human rights, as a practical proposal for introducing universal standards in business.

\section{Is Moral Diversity a Good Argument for Moral Relativism?}

Moral diversity among cultures is not a novelty. Among the ancient Greek philosophers, moral diversity was widely acknowledged (Gowans 2012), as it was with Medieval thinkers, like Thomas Aquinas (das Neves and Melé 2013). Modern cultural anthropologists have also empirically shown that moral diversity is a matter of fact (e.g., Benedict 1934). A fundamental question is whether the existence of moral diversity is a good argument to support moral relativism. While the former is peacefully accepted by almost all, many reject "moral relativism, or more precisely "normative moral relativism." Moral relativists defend the position that there are neither objective ethics nor universal ethics; the only source of truth for morality is each cultural context. According to Gowans (2012), moral relativists state that "the truth or falsity of moral judgments, or their justification, is not absolute or universal, but is relative to the traditions, convictions, or practices of a group of persons." He terms this philosophical position "Metaethical Moral Relativism." This author explains this approach through the statement "Polygamy is morally wrong," which may be true relative to one society, but false relative to another. Similar examples could include cutting off a hand when someone is caught stealing, the mutilation of female genitals, or in a business context, tolerating bribery and harming the environment. Obviously, one can claim that these actions are assumed as right in reference to norms shared in certain societies that endorse them, but this does itself not probe by itself the truth of a moral judgment, especially when colliding with solid trans-cultural ethical referents, such as respect of human dignity or the Golden Rule. A moral judgment may be passed in one society, but not in another, this being a 
matter for sociological verification. But this is not the same as justifying and legitimating a given moral judgment as good or right.

Two papers here deal with moral relativism, although this is not their central topic. From different perspectives, both agree that moral diversity is not a good argument for moral relativism. The first paper is authored by Carlos $\mathrm{J}$. Sanchez-Runde, Luciara Nardon, and Richard M. Steers, all with expertise in cross-cultural management. They describe and discuss the cultural roots of ethical conflicts in the global business environment. They emphasize the importance of understanding moral diversity along with ethical conflicts in multiple levels within the same organization or industry, and the meaning of universal values and the relationship between values and practices. These authors state that values are universal but their universalism can only be accessed incrementally. They bring a text on the effects of the atomic bombing of Hiroshima from the literature Nobel laureate Kenzaburo Oé to illustrate the point that the richness of the concept of human dignity is beyond words, that no human language will ever fully make it justice, and that one can improve its understanding through time and space. They argue that people and cultures evolve over time and space, and so do their ethical beliefs and values. At times, these values run somewhat in tandem across cultures to give the impression of a universal form of access - understanding and application - to those values. This can be seen very clearly in many commonly espoused beliefs (respect your neighbors, protect the defenseless...) that can be found in various religions. At other times, however, this convergence seems to disappear. Their conclusion is that from a descriptive viewpoint, ethical values are not universal over time and space but they do become universal through time and space. We then make progress in accessing ethical values.

The second paper, by Daryl Koehn, devotes a part of its discussion to clarifying some mistaken notions that lead to cultural ethical relativism. One is that moral relativists often begin by pointing to the wide variety of human experience, and no one contests the existence of such variety. This happens because of focusing too much on the details and failing to search for overarching ethic good and/ or virtues underpinning diverse human practices. Another objection against some moral relativists is that they consider cultures as static and monolithic, when actually they are not. Some members of a culture may be more practically wise than others, and each culture contains resources and concepts for interpreting a universal virtue such as justice in a variety of ways in light of new conditions and circumstances. Over time -she affirms-, "these intra-cultural manifestations may converge as agents refine their judgments in light of experience interpreted by reason and in light of arguments advanced by especially thoughtful members of the community." A third argument given by Koehn is that moral relativists wrongly assume that issues can only be successfully addressed in one way within another culture. This assumption leads them to conclude wrongly that this other culture operates with an ethical compass different from our own. This has a significant application in business when some affirm that it is morally acceptable to pay bribes when doing transactions in Asia. Many Scandinavian companies, for instance, do business in Asia without paying bribes.

\section{Common Values Worldwide and Universal Virtues}

While moral diversity is a matter of fact, as noted, some add that disagreements across different societies are much more significant than whatever agreements there may bethis is called "Descriptive Moral Relativism" (Gowans 2012). Authors in disagreement with this proposition point that there is a universal minimal morality, whatever other moral differences there may be (e.g., Bowie 1990; Walzer 1994; Bok 2002). According to this latter scholar, "certain basic values necessary for collective survival have had to be formulated in every society. A minimalist set of such values can be recognized across societal and other boundaries." (Bok 2002, p. 12).

Several empirical research works show that beyond specific moral judgments there can be found basic values or principles underlying those judgments, and these common values and principles appear in the major religions and wisdom traditions worldwide. Thus, Lewis (1987) and Moses (2001) identified a number of foundational principles shared by all religions, the Golden Rule (Wattles 1996) among others (Terry 2011; Tullberg 2011). Other findings recognize the more or less latent presence of common values in when surveying the world's major religious traditions (Kidder 1994; Dalla Costa 1998; Küng 1996; 1998). Hengda (2010), for instance, traced within Chinese traditional ethics (Confucius, Mencius, MoTzu...) the universal values of humanity and reciprocity included in the Declaration toward a Global Ethics of Humanity. This Declaration was formulated by the Second Parliament of the World's Religions, which 6,500 delegates from all over the world attended in Chicago in 1993.

If we look at the great diversity of character traits presented as virtues throughout history and societies, Dahlsgaard et al. (2005) found a set of core virtues across religions and cultures (Confucianism, Buddhism, Hinduism, Athenian, Judeo-Christian, Islamic, among others). Their findings show that there is convergence across time, place and intellectual tradition about certain core virtues: wisdom, justice, courage, temperance, humanity, and transcendence. These core virtues are "ubiquitous, if not 
universal" (Peterson and Seligman 2004, p. 33), and they are not too far from the four traditional "cardinal virtues" proposed firstly by Plato (Finance 1991, p. 485) and then on by many other authors: prudence (practical wisdom), justice, fortitude (courage), and temperance (moderation or self-control).

Two papers of this issue focus on universal virtues. Daryl Koehn, apart from the above-mentioned discussion on moral relativism, also shows how Aristotle's virtue ethic strongly resembles that of Confucius. This similarity derives from what they each take to be objective facts about human nature and developmental aspects of virtue. This similarity suggests that a universal virtue ethic may already exist in the form of a powerful shared strand of moral thinking. Morales and Cabello focus on the traditional cardinal virtues, which they consider universal and essential moral competencies for managerial decision-making. They discuss the influence of these virtues on moral sensitivity, moral judgment, moral motivation, and moral character. Prudence will influence moral sensitivity, moral judgment, and moral motivation. Justice will influence the component of the ethical decision-making process mainly related with human will: moral motivation and moral character. Temperance will help to create moral motivation to develop ethical behavior. Finally, fortitude will reinforce the moral character to engage the ethical behavior.

\section{Moral Universalism}

In opposition to moral relativism, moral universalismalso called moral objectivism-holds that there are objective right or wrong actions, independently of the social or personal values or opinions. There are well-known approaches in business ethics which fall within the domain of moral universalism, such as Kantian deontology, Natural Rights Theory, Utilitarianism, and several forms of Contractualism. Moral universalism can be, or not, moral absolutism. This latter, as in Kantian Ethics (Bowie 1999), defends the position that the morality of some actions is independent of context or consequences. Non-absolutist moral universalism, such as Consequentialism and its more popular form, Utilitarianism (Snoeyenbos and Humber 2002), or Integrative Social Contracts Theory (Donaldson and Dunfee 1999) consider both universal norms and local norms to evaluate the morality of an action.

Universalist theories like these mentioned provide sound ethical standards or criteria for conducting business, but they also present some problems. Some of them are based on different aprioristic rational principles (the Categorical Imperative in Kant, the Utilitarian principle in Utilitarianism, and so on). Thus, various ethical theories compete. In addition, Neo-Aristotelians criticize agent-neutral theories for not considering individual character in making moral judgments.

Moral universalism is indirectly considered in the article by Prabhir Vishnu Poruthiyil, included in this issue, from a critical position. He argues that business ethicists-many of whom propose universal theories-state obligations for multinationals which could contribute to the well-being of individuals in developing countries. In addition, some of them have offered strategies to achieve this goal. However, their results are limited. Despite the good intentions, business ethics theories aiming at fulfilling social goals can be rendered ineffectual when economic goals are prioritized. He then postulates a "developmental ethics" approach calling on multinational companies to change their primary focus from profit generation to social justice. $\mathrm{He}$ argues that this approach, opposed to mere economism, offers more nuanced approaches than those now available in business ethics literature.

\section{Universal Ethics through the Natural Moral Law}

A different perspective on universal ethics come from the natural moral law tradition (Murphy 2011), with roots in several authors of ancient Greece and Rome including Cicero, and medieval thought, particularly Thomas Aquinas'. Natural law is mentioned in the Bible (1966), as rationally accessible for unbelievers. St. Paul writes: "When Gentiles, who do not have the law, do by nature things required by the law, they are a law for themselves, even though they do not have the law. They show that the requirements of the law are written on their hearts, their consciences also bearing witness, and their thoughts sometimes accusing them and at other times even defending them." (Rom 2: 14-15).

Cicero suggested the existence of a Reason (mens, in Latin) that rules the whole world, which he describes as a fully superior and divine, not mediated, "nature law" (lex naturae) that is universal, absolutely primal, invariable and eternal, which humans should try to know and apply in their lives (Corso de Estrada 2008). Cicero is aligned with the Stoic moral philosophy view of the natural law when he synthesized that "living according to nature consists in living according to the dictates of right reason, which is quite clearly thought of as the common or universal law" (Horsley 1978, p. 40).

Similarly, although with some differences to Cicero, Aquinas accepted human beings are endowed with certain capacity (practical reason) that allows us to distinguish good from evil-what is truly good for human flourishing from what is not-at least in some minimalistic aspects. Thus, humans can know natural law, which "is nothing else than the rational creature's participation of the eternal 
law." (Aquinas 1981, I-II 91, 2) Aquinas focused on the rational nature of the human being and consequently his natural law theory is directly founded on the basic elements of humanity. It is a universal ethics which also accounts for diversity. In addition, Cicero held that natural law obliges us to contribute to the general good of the larger society (Barham 1841-42, Introduction). Aquinas also included moral responsibilities toward the common good of the society (Finnis 1998, pp. 234ff).

After a period of certain decadence and criticism (George 1999), natural law theory has experienced a revival since the middle of the last century (Maritain 1971, 2001; Finnis 1980; Rhonheimer 2000; Murphy 2001, among others), and some recently suggest a new look at natural law (ITC 2009), including Pope Benedict XVI (2008) in his speech to the General Assembly of the United Nations. He related the UN Universal Declaration of Human Rights of 1948 to natural law by affirming that "the rights recognized and expounded in the Declaration apply to everyone by virtue of the common origin of the person, who remains the high-point of God's creative design for the world and for history. They are based on the natural law inscribed on human hearts and present in different cultures and civilizations." (our Italics).

In this issue, two papers refer to natural law, one focused on Cicero and another on Aquinas. Cicero's natural law and his ideas on virtuous behavior are taken into consideration by Michael Aßländer in his contribution. He focuses on Cicero by arguing that this Roman Stoic philosopher presented important concepts and approaches from which we can learn for business ethics. After summarizing the specific Ciceronian understanding of natural law and virtuous behavior, he analyzes honorableness and beneficialness, two key distinct qualities according to Cicero. This Roman thinker had the conviction that honorableness depends on respecting universal ethical principles. Wise people, following their true nature, fulfill their natural duties toward fellow-citizens and do no harm others. For Cicero, Aßländer affirms, what is honorable is always useful, because the honorable person strives for the common good, and therefore serves the community and benefits all. He argues that, from a Ciceronian perspective, what is honorable may not necessarily be profitable; honorable behavior and profitable behavior may conflict. Aßländer argues that reputation must be seen as an independent issue which might influence financial opportunities but, first of all, derives from the fulfillment of duties that go beyond purely economic considerations. Reputation derives solely from honorable behavior and the orientation toward the common good. Consequently, corporate reputation will only be achieved if it is based primarily on "honorableness," and that reputation will be lost if financial interests override the honest intentions of a company.

\section{Human Rights as Universal Standards for Business}

One important step in applying universal ethics is through human rights, and more specifically the international declarations of human rights, beginning with the Universal Declaration of Human Rights (UDHR) (1948), and followed by other UN human rights covenants and ILO Conventions, including the International Covenant on Economic, Social, and Cultural Rights adopted by the United Nations General Assembly in 1966, along with an optional protocol added in 2008, which presents an exhaustive list of rights in the labor context, and the UN Global Compact with its ten ethical principles for business.

Article 1 of the UDHR begins with the well-known statement that "All human beings are born free and equal in dignity and rights. They are endowed with reason and conscience and should act toward one another in a spirit of brotherhood." This is a significant ethical statement addressed to humankind. However, the proposal presents two important issues to be debated, one theoretical and the other practical. The theoretical regards the foundation of human rights. As the Declaration of the Parliament of the World's Religions (1993) pointed out, rights without morality cannot long endure. Without a solid foundation, any claim supported by strong lobbies can eventually be presented as a human right. The practical problem refers to the implementation of human rights and the role that business should play in this matter. At this point, it is worth noting the recent idea that protecting and promoting human rights is not only a task of states but also of civil society and business. We can point to, John Ruggie's recent reports (Ruggie 2008, 2011, 2013) which former UN SecretaryGeneral Kofi Annan commissioned in 2005. The last of those reports, significantly entitled: "Protect, Respect, and Remedy: A Framework for Business and Human Rights" (Ruggie 2011) is particularly relevant for our purposes, as so are the "Guiding Principles on Business and Human Rights" to implement the Framework.

Two papers included in this special issue focus on Ruggie's reports and the Guiding Principles. One is authored by Matthew Murphy and Jordi Vives. Drawing from several celebrated scholars, they hold that the equal treatment of all people as humans-conditio humana-is the constitutive, defining characteristic of universal human rights. Even accepting that ethical values may differ among cultures, seemingly divergent values converge at key points, such as respect for human dignity, respect for basic rights and good citizenship. In addition, human rights are the most important and fundamental category of moral rights that protect those freedoms which are most essential for a dignified and self-determined human life. Their main aim is, however, not to discuss this, but some problems related to Ruggie's Framework. They apply concepts from 
the field of 'organizational justice' to the arena of business and human rights for the purpose of operationalizing this Framework. They argue that there could be a gap between perceptions of justice held by stakeholders versus businesses and/or the State. Through theoretical considerations and by analyzing a case study - the Goldcorp's Marlin Mine in Guatemala-they show the potential for complicity of businesses in human rights abuses and expose a fundamental weakness in a UN Framework, that draws too sharp a distinction between duties of States and responsibilities of businesses.

The other paper, by Björn Fasterling and Geert Demuijnck analyses UN Guiding Principles on Business and Human Rights. The authors identify tensions for corporations between respecting human rights as "perfect moral duty" admitting no exceptions and "human rights due diligence" to which companies should morally commit. They argue that the due diligence approach falls short of the requirements implied by the respect of human rights as perfect moral duty, inasmuch as the Guiding Principles leave room for an instrumental or strategic implementation of due diligence. This can then result in a depreciation of the fundamental norms the UN seeks to promote. They suggest that to make further progress in international and extraterritorial human rights law we also need a more forceful discussion on the moral foundations of human rights duties for corporations.

To conclude, we hope that this special issue may make a contribution to the current debate on cultural diversity and universal ethics, particularly in a global world, further discussion and research. Apart from academic research, ethics in culturally diverse and global environments may require the opening of closed attitudes too strongly secluded in technical and economics viewpoints, for they display certain disregard for what we have in common as humans. Benedict XVI once wrote that "as society becomes ever more globalized, it makes us neighbors but does not make us brothers." (2009, n. 16). Indeed, global and local processes, along with tensions of interconnectedness and separation do impact on the content and structure of human relationships. In our view, these relationships only become truly human by advancing in the current rebuilding of our common human family.

\section{References}

Aquinas, T. (1981)[1273]. Summa theologiae. London: Burns Oates and Washbourne, Ltd.

Barham, F. (1841-1842). Introduction to the political works of Marcus Tullius Cicero: Comprising his treatise on the commonwealth; and his treatise on the laws. Translated from the original, with dissertations and notes (Vol. 2). London: Edmund Spettigue. Retrieved February 25, 2013 from http:// oll.libertyfund.org/index.php?option=com_content\&task=view\& $\mathrm{id}=747 \&$ Itemid $=284$.

Benedict, R. (1934). Patterns of culture. New York: Penguin.

Benedict XVI. (2008). Address to General Assembly of the United Nations Organization, April, 18. Retrieved February 25, 2013 from http://www.vatican.va/holy_father/benedict_xvi/speeches/2008/ april/documents/hf_ben-xvi_spe_20080418_un-visit_en.html.

Benedict XVI. (2009). Encyclical Letter 'Caritas in veritate'. Retrieved February 25, 2013 from http://www.vatican.va/holy_ father/benedict_xvi/encyclicals/documents/hf_ben-xvi_enc_2009 0629_caritas-in-veritate_en.html.

Bible, The Holy. (1966). New revised standard version. Princeton, NJ: Scepter.

Bok, S. (2002). Common values. Columbia, MO: University of Missouri Press.

Bowie, N. E. (1990). Business ethics and cultural relativism. In P. Madsen \& J. M. Shafritz (Eds.), Essentials of business ethics (pp. 366-382). New York: Meridian.

Bowie, N. E. (1999). Business ethics: A kantian perspective. Oxford: Blackwell.

Corso de Estrada, L. E. (2008). Marcus Tullius Cicero and the role of nature in the knowledge of moral good. In A. N. García, M. Šilar, \& J. M. Torralba (Eds.), Natural law: Historical, systematic and juridical approaches (pp. 9-21). Cambridge, MA: Cambridge Scholars Publishing.

Dahlsgaard, K., Peterson, C., \& Seligman, M. E. P. (2005). Shared virtue: The convergence of valued human strengths across culture and history. Review of general psychology, 9(3), 203-213.

Dalla Costa, J. (1998). The ethical imperative: Why moral leadership is good business. Toronto: HarperCollins Publishers.

das Neves, J. C. and Melé D. (2013). Managing ethically cultural diversity: learning from Thomas Aquinas, Journal of Business Ethics. This issue.

Donaldson, T. (1996). Values in tension: Ethics away from home. Harvard Business Review, 74(5), 48-57.

Donaldson, T., \& Dunfee, T. (1999). Ties that bind: A social contracts approach to business ethics. Boston, MA: Harvard Business School Press.

Finance, J. D. (1991). An ethical inquiry. Roma: Editrice Pontificia Università Gregoriana.

Finnis, J. (1980). Natural law and natural rights. Oxford: Clarendon Press.

Finnis, J. (1998). Aquinas: Moral, political, and legal theory (founders of modern political and social thought). Oxford: Oxford University Press.

Frederick, R. E. (2002). An outline of ethical relativism and ethical absolutism. In R. E. Frederick (Ed.), A companion to business ethics (pp. 65-80). Oxford: Blackwell.

George, R. P. (1999). Defense of natural law. Oxford: Clarendon Press.

Gowans, C. (2012). Moral relativism. In E. N. Zalta (Eds.) The Stanford encyclopedia of philosophy (http://plato.stanford.edu/ archives/spr2012/entries/moralrelativism/. Firstly published February 2004 and with a substantive revision in December 2009, and a minor correction in 2012.

Hengda, Y. (2010). Universal values and Chinese traditional ethics. Journal of International Business Ethics, 3(1), 81-90.

Horsley, R. A. (1978). The law of nature in philo and cicero. Harvard Theological Review, 71(1-2), 35-59.

ITC (International Theological Commission). (2009). In search of a universal ethic: A new look at the natural law. Retrieved February 25, 2013 from http://www.vatican.va/roman_curia/ congregations/cfaith/cti_documents/rc_con_cfaith_doc_20090520_ legge-naturale_en.html).

Jhingran, S. (2001). Ethical relativism and universalism. New Delhi: Motilal Banarsidass Publishers. 
Kidder, R. M. (1994). Universal human values. Futurist, 28(4), 8-13. Krausz, M. (Ed.). (1989). Relativism. Interpretation and confrontation. Notre Dame, IN: Notre Dame University Press.

Küng, H. (Ed.). (1996). Yes to a global ethic: Voices from religion and politics. New York, NY: Continuum.

Küng, H. (1998). A global ethics for global politics and economics. Oxford: Oxford University Press.

Lewis, C. S. (1987). The abolition of man. London: Curtis Brown.

Maritain, J. (1971) [1943]. The rights of man and natural law. New York : Gordian Press.

Maritain, J. (2001). Natural law: Reflections on theory and practice. South Bend, IN: St. Augustine's Press.

Melé, D. (2012). Management ethics: Placing ethics at the core of good management. New York, NY: Palgrave MacMillan.

Moses, J. (2001). Oneness: Great principles shared by all religions. New York, NY: Ballantine Books.

Murphy, M. C. (2001). Natural law and practical rationality. New York: Cambridge University Press.

Murphy, M. (2011). The natural law tradition in ethics. In E. N. Zalta (Eds.) The Stanford encyclopedia of philosophy. Retrieved February 25, 2013 from http://plato.stanford.edu/archives/ win2011/entries/natural-law-ethics/.

Parliament of the World's Religions (1993) Declaration toward a global ethics-Chicago. Retrieved February 25, 2013 from www.weltethos.org/data-en/c-10-stiftung/13-deklaration.php.

Peterson, C., \& Seligman, M. (2004). Character strengths and virtues: A handbook and classification. Washington, DC: American Psychological Association.

Rhonheimer, M. (2000). Natural law and practical reason: A Thomist view of moral autonomy. New York, NY: Fordham University Press.
Ruggie, J. G. (2008). Protect, respect and remedy: A framework for business and human rights. UN Doc A/HRC/8/5. Retrieved February 25, 2013 from http://198.170.85.29/Ruggie-report-7Apr-2008.pdf.

Ruggie, J. G. (2011). Guiding principles on business and human rights: Implementing the United Nations "protect, respect and remedy" framework. UN Doc A/HRC/17/31. Retrieved February 25, 2013 from http://www.ohchr.org/Documents/Issues/Business/A-HRC17-31_AEV.pdf.

Ruggie, J. (2013). Just business: Multinational corporations and human rights. London: WW Norton \& Company.

Snoeyenbos, M., \& Humber, J. (2002). Utilitarianism and business ethics. In R. E. Frederick (Ed.), A companion to business ethics (pp. 17-29). Oxford: Blackwell.

Terry, H. (2011). Golden rules and silver rules of humanity. Concord, MA: Infinite Publishing.

Tullberg, J. (2011). The golden rule of benevolence versus the silver rule of reciprocity, Journal of Religion and Business Ethics 3(1). Retrieved February 25, 2013 from http://via.library.depaul.edu/ jrbe/vol3/iss1/2.

United Nations: 1948, The Universal Declaration of Human Rights. Retrieved February 25, 2013 from http://www.un.org/en/ documents/udhr/index.shtml.

Vendemiati, A. (2008). Universalismo e relativismo nell'etica contemporanea. Milano: Marietti.

Walzer, M. (1994). Thick and thin: Moral argument at home and abroad. Notre Dame, IN: University of Notre Dame Press.

Wattles, J. (1996). The golden rule. New York, NY: Oxford University Press. 